DOI: https://doi.org/10.24127/ajpm.v9i4.3167

\title{
PENGEMBANGAN BAHAN AJAR EDUCATIONAL STATISTICS UNTUK MENINGKATKAN KEMANDIRIAN DAN HASIL BELAJAR MAHASISWA
}

\author{
Dwi Astuti ${ }^{1 *}$, Anggit Prabowo ${ }^{2}$ \\ ${ }^{*}, 2$ Pendidikan Matematika, Universitas Ahmad Dahlan, Yogyakarta, Indonesia \\ ${ }^{*}$ Corresponding author. Samiran Parangtritis Kretek, 55772, Bantul, Indonesia. \\ E-mail: $\quad$ dwi.astuti@pmat.uad.ac.id ${ }^{\left.{ }^{*}\right)}$ \\ anggit.prabowo@pmat.uad.ac.id $^{2)}$
}

Received 18 October 2020; Received in revised form 24 December 2020; Accepted 29 December 2020

\begin{abstract}
Abstrak
Penelitian ini bertujuan untuk mengembangkan bahan ajar educational statistics untuk meningkatkan kemandirian belajar dan hasil belajar mahasiswa. Penelitian ini menggunakan jenis penelitian Research and Development tipe 4D (Define, Design, Develop, dan Disseminate). Instrumen yang digunakan dalam penelitian ini adalah lembar validasi ahli, kuesioner kemandirian belajar, dan tes hasil belajar. Subjek dalam penelitian ini adalah 98 mahasiswa Program Studi Pendidikan Bahasa Inggris Universitas Ahmad Dahlan yang sedang menempuh mata kuliah educational statistics. Berdasarkan hasil pengembangan diketahui bahwa bahan ajar educational statistics memenuhi kriteria valid, dan penggunaan bahan ajar tersebut efektif ditinjau dari kemandirian belajar dan hasil belajar mahasiswa. Tetapi penggunaan bahan ajar educational statistics ini tidak lebih efektif jika dibandingkan dengan penggunaan bahan ajar lain
\end{abstract}

Kata kunci: educational statistics; hasil belajar; kemandirian belajar

\begin{abstract}
This study aims to develop an educational statistics module to increase learning independence and student learning outcomes. This study used research and development type 4D (Define, Design, Develop, and Disseminate). The instruments used in this study were expert validation sheets, independent learning questionnaires, and learning outcomes tests. The subjects in this study were 98 students of the Ahmad Dahlan University English Education Study Program who are currently taking educational statistics courses. Based on the development results, it is known that the educational statistics module meets valid criteria, and the use of the module is effective in terms of learning independence and student learning outcomes.
\end{abstract}

Keywords: educational statistics; learning independence; learning outcome

This is an open access article under the Creative Commons Attribution 4.0 International License

\section{PENDAHULUAN}

Dalam kegiatan perkuliahan bahan ajar memiliki peranan yang sangat penting bagi dosen dan mahasiswa. Beberapa peran bahan ajar bagi dosen yaitu menghemat waktu dalam mengajar, proses pembelajaran menjadi lebih efektif dan menarik (Aisyah, Noviyanti, \& Triyanto, 2020; Tian, 2003). Selain itu, penggunaan bahan ajar dalam pembelajaran statistika dapat meningkatkan kemandirian belajar siswa (Merona, 2019). Bahan ajar educational statistics yang dirancang dengan pembelajaraan kooperatif dapat meningkatkan aktivitas dan kerjasama peserta didik (Astuti, 2019).

Kemandirian belajar merupakan salah satu kemampuan siswa untuk dapat mengendalikan dan mengatur perilakunya, serta dapat mengevaluasi pembelajarannya sendiri untuk mencapai tujuan (Day \& Connor, 2012; 
Marchis, 2011; Timmons, Pelletier, \& Corter, 2016). Kemandirian belajar memiliki beberapa indikator yaitu: (a) personal regulation, meliputi: organisasi dan tranformasi; penataan tujuan dan rencana; mencari informasi; latihan dan mengingat kembali; meninjau kembali catatan. (b) behavioral pervormance, meliputi : evaluasi diri; membuat catatan; konsekuensi diri. (c) learning environment, meliputi: menata lingkungan; mencari bantuan sosial (Cole \& Chan, 1994).

Kemandirian belajar siswa diperlukan agar mereka mempunyai tanggung jawab dalam mengatur dan mendisiplinkan dirinya, serta dalam mengembangkan kemampuan belajar atas kemauan sendiri. Kemandirian belajar sangat penting untuk proses pembelajaran (Järvelä \& Järvenoja, 2011; Zimmerman, 2008). Kemandirian belajar ini dapat membantu siswa menciptakan kebiasaan belajar yang lebih baik dan memperkuat keterampilan belajar mereka (Wolters, 2011), menerapkan strategi pembelajaran untuk meningkatkan hasil belajar (Harris, Friedlander, Saddler, Frizzelle, \& Graham, 2005; Zumbrunn, 2011), memantau kinerja siswa (Harris et al., 2005), dan mengevaluasi kemajuan belajar siswa (de Bruin, Thiede, Camp, \& Redford, 2011).

Berdasarkan hasil observasi di kelas mata kuliah Statistika pada Program Studi non Matematika, sebagian besar mahasiswa menyatakan bahwa salah satu alasan mereka memilih program studi tersebut adalah mereka tidak akan bertemu dengan matematika. Berikut hasil survey tentang pendapat mahasiswa tentang statistika pada perkuliahan educational statistics disajikan pada Gambar 1.

\section{Apa yang Anda pikirkan tentang statistika?}

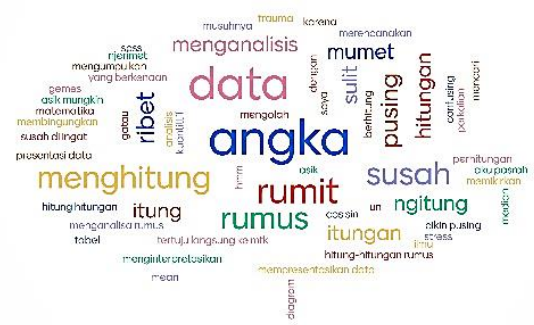

Gambar 1. Hasil survey mahasiswa tentang statistika.

Beberapa kesan negatif yang muncul dari hasil survey yaitu rumit, ribet, pusing, membosankan, susah diingat, trauma, dan stress. Kesan-kesan yang negative tersebut menjadi salah satu indikator rendahnya minat mahasiswa pada mata kuliah educational statistics. Rendahnya minat belajar ini akan berakibat pada rendahnya keinginan mahasiswa untuk belajar secara mandiri. Selain intu, rendahnya minat akan berpengaruh pada rendahnya hasil belajar (Wilda, Salwah, \& Ekawati, 2017). Permasalahanpermasalahan tersebut muncul karena beberapa faktor diantaranya proses pembelajaran, media pembelajaran, dan bahan ajar. Sebagian besar siswa di tingkat Sekolah Menengah Atas tidak menyukai matematika karena beberapa faktor yaitu faktor kesulitan untuk memahami materi, faktor guru, atau faktor instruksional (Gafoor \& Kurukkan, 2015).

Berkaitan dengan persepsi negatif tentang faktor instruksional khususnya ketersediaan bahan ajar, mahasiswa menyatakan bahwa bahan ajar atau buku statistika yang sudah ada belum menyajikan materi yang sesuai dengan kebutuhan materi yang dipelajari. Materi yang dipelajari sudah sesuai dengan kurikulum KKNI. Selain itu, buku-buku yang yang digunakan oleh mahasiswa belum dilengkapi dengan 
DOI: https://doi.org/10.24127/ajpm.v9i4.3167

video tutorial analisis data menggunakan aplikasi-aplikasi analisis data.

Ketersediaan bahan ajar educational statistics akan memudahkan mahasiswa untuk belajar secara mandiri. Selama ini mahasiswa terlihat tidak mempelajari materi sebelum dosen menjelaskan. Mahasiswa mempersiapkan materi atau belajar jika dosen meminta saja. Selain itu, mahasiswa hanya mengandalkan materi yang diberikan oleh dosen dalam bentuk file powerpoint saja. Hasil penelitian juga menunjukkan bahwa kemandirian belajar siswa masih cenderung rendah (Azka \& Santoso, 2015; Hidayat, Akbar, \& Bernard, 2008; Marchis, 2011).

Beberapa penelitian yang sudah dilakukan untuk mengembangkan bahan ajar statistika. Penelitian tentang bahan ajar statistika untuk jenjang SMP dilakukan oleh (Latifah \& Widjajanti, 2017) menunjukkan bahwa pengembangan bahan ajar statistika dan peluang yang dikembangkan untuk siswa SMP memenuhi kriteria valid, praktis dan efektif ditinjau dari prestasi belajar, kemampuan pemecahan masalah, dan rasa ingin tahu. Selain itu, pengembangan bahan ajar gamifikasi pada materi statistika yang dilakukan oleh (Rembulan, Wahyu, \& Putra, 2018) menunjukkan bahwa bahan ajar yang dikembangkan valid dan dapat menarik minat siswa untuk belajar. Pada tingkat Perguruan Tinggi, perangkat pembelajaran yang berupa silabus, Satuan Acara Perkuliahan (SAP), dan bahan ajar pada mata kuliah statistika dasar dikembangkan dengan dengan pendekatan Problem Based Learning dapat meningkatkan prestasi belajar mahasiswa (Krisdiana, 2016). Hal ini diperkuat dengan penelitian yang dilakukan oleh (Numan, 2019) yang menunjukkan bahwa pengembangan bahan ajar statistika pendidikan untuk mahasiswa mendapatkan respon yang sangat baik ditunjukkan dengan rasa senang dan antusias dari mahasiswa ketika menggunakan bahan ajar tersebut.

Oleh karena itu, tujuan penelitian ini adalah untuk mengembangkan bahan ajar educational statistics yang valid, praktis, dan efektif ditinjau dari kemandirian belajar dan hasil belajar mahasiswa. Bahan ajar yang dikembangkan merupakan bahan ajar educational statistics untuk mahasiswa memuat materi ajar, contoh penyelesaian soal, dan dilengkapi dengan barcode video tutorial penggunaan teknologi komputer dalam proses analisis data.

\section{METODE PENELITIAN}

Penelitian ini merupakan penelitian pengembangan dengan model 4D, yaitu define, design, develop, dan disseminate. Beberapa poin yang dilakukan pada tahap define yaitu melakukan analisis kebutuhan bahan ajar, menentukan karakteristik mahasiswa, dan menganalisis materi. Pada tahap design, dilakukan beberapa tahap yaitu pemilihan bahan ajar, menentukan karakteristik bahan ajar, dan perancangan awal bahan ajar. Pada tahap develop dilakukan pengembangan bahan ajar sesuai rancangan awal, validasi oleh ahli, dan uji coba atau uji efektivitas. Tahap terakhir yaitu disseminate, merupakan tahap penyebarluasan bahan ajar yang dikembangkan.

Subjek dalam penelitian ini adalah mahasiswa yang menempuh mata kuliah educational statistics pada program studi Pendidikan Bahasa Inggris FKIP UAD. Subjek pada penelitian ini berjumlah 98 mahasiswa yang terbagi 
dalam dua kelas berbeda. Pada tahap uji efektivitas bahan ajar, dipilih semua sebagai sampel. Mahasiswa dalam kelas pertama sebagai kelas eksperimen dan mahasiswa dalam kelas kedua sebagai kelas kontrol.

Setelah selesai pengembangan bahan ajar dilakukan validasi oleh ahli materi. Instrumen yang digunakan pada tahap ini adalah lembar validasi dengan menggunakan indikator sebagai berikut: kesesuaian materi/isi, kesesuaian dengan standar proses, kesesuaian dengan syarat konstruksi, dan kesesuaian dengan syarat teknis. Instrumen terdiri atas 26 butir dengan penilaian menggunakan skala Likert (1 sampai 5). Table kriteria penilaian kevalidan bahan ajar oleh ahli disajikan pada Tabel 1.

Tabel 1. Kriteria penilaian kevalidan dan kepraktisan bahan ajar

\begin{tabular}{ll}
\multicolumn{1}{c}{ Interval } & \multicolumn{1}{c}{ Kriteria } \\
\hline $\mathrm{Mi}+1,5 \mathrm{Si}<\mathrm{X}$ & Sangat valid/praktis \\
$\mathrm{Mi}+0,5 \mathrm{Si}<\mathrm{X} \leq \mathrm{Mi}+1,5 \mathrm{Si}$ & Valid/praktis \\
$\mathrm{Mi}-0,5 \mathrm{Si}<\mathrm{X} \leq \mathrm{Mi}+0,5 \mathrm{Si}$ & Cukup valid/praktis \\
$\mathrm{Mi}-1,5 \mathrm{Si}<\mathrm{X} \leq \mathrm{Mi}-0,5 \mathrm{Si}$ & Kurang valid/praktis \\
$\mathrm{X} \leq \mathrm{Mi}-1,5 \mathrm{Si}$ & Tidak valid/praktis \\
\hline
\end{tabular}

(Azwar, 2013)

Keterangan:

$\mathrm{X}=$ total skor aktual

$\mathrm{Mi}=$ rata-rata skor ideal $=\frac{1}{2}$ (skor maksimum + skor minimum)

$\mathrm{Si}=$ simpangan baku ideal $=\frac{1}{6}$ (skor maksimum - skor minimum)

Bahan ajar dikatakan valid jika skor kevalidan dari ahli lebih dari 86,67.

Langkah berikutnya adalah menguji kepraktisan dari bahan ajar yang dikembangkan. Instrument yang digunakan adalah angket kepraktisan bahan ajar yang terdiri atas 15 butir dengan menggunakan skala Likert. Berdasarkan kriteria pada Tabel 1, maka bahan ajar dikatakan praktis jika ratarata skor kepraktisan minimal 50.

Sedangkan pada tahap uji efektivitas, bahan ajar diuji efektivitasnya ditinjau dari kemandirian belajar dan hasil belajar. Instrumen untuk mengukur kemandirian belajar adalah angket kemandirian belajar. Indikator kemandirian belajar yang digunakan yaitu pengaturan diri, kebiasaan kerja, dan lingkungan belajar. Angket kemandirian belajar terdiri atas 40 butir pernyataan. Sedangkan instrument yang digunakan untuk mengukur hasil belajar adalah tes essay. Tes dikembangkan berdasarkan materi yang dikembangkan yaitu statistika deskriptif. Materi statistika deskriptif meliputi penyajian data, ukuran gejala pusat, ukuran letak data, dan ukuran penyebaran data.

Langkah pertama dalam analisis ini yaitu menguji asumsi normalitas dan homogenitas data dipenuhi atau tidak. Jika data berdistribusi normal maka dilanjutkan pengujian hipotesis dengan tahapan berikut:

Hipotesis Uji perbedaan rata-rata untuk data sebelum perlakuan (pretest)

$$
\begin{aligned}
& H_{0}:\left(\begin{array}{l}
\mu_{H B(E)} \\
\mu_{K B(E)}
\end{array}\right)=\left(\begin{array}{l}
\mu_{H B(K)} \\
\mu_{K B(K)}
\end{array}\right) \\
& H_{1}:\left(\begin{array}{l}
\mu_{H B(E)} \\
\mu_{K B(E)}
\end{array}\right) \neq\left(\begin{array}{l}
\mu_{H B(K)} \\
\mu_{K B(K)}
\end{array}\right)
\end{aligned}
$$

Dimana $\mu_{H B(E)}$ menyatakan ratarata hasil belajar kelas eksperimen dengan menggunakan bahan ajar educational statistics dan $\mu_{K B(E)}$ menyatakan rata-rata skor kemandirian belajar mahasiswa kelas eksperimen dengan menggunakan bahan ajar educational statistics. Sedangkan $\mu_{H B(K)}$ menyatakan rata-rata hasil belajar kelas kontrol dengan tidak menggunakan bahan ajar educational statistics yang dikembangkan dan $\mu_{K B(K)}$ menyatakan rata-rata skor kemandirian belajar mahasiswa kelas 
kontrol dengan tidak menggunakan bahan ajar educational statistics yang dikembangkan. Pengujian hipotesis dilakukan dengan menggunakan SPSS dengan kriteria penolakan yaitu $\mathrm{H}_{0}$ ditolak jika nilai signifikansinya lebih kecil dari 0,05.

\section{Uji keefektifan}

Pengujian ini dilakukan untuk mengetahui apakah bahan ajar educational statistics yang dikembangkan efektif ditinjau dari kemandirian belajar dan hasil belajar mahasiswa. Pengujian dilakukan menggunakan uji $\mathrm{t}$ dengan program SPSS. Kriteria pengujiannya adalah $\mathrm{H}_{0}$ ditolak jika nilai signifikansinya lebih kecil dari 0,05. Jika penggunaan bahan ajar yang dikembangkan pada kelas eksperimen dan penggunaan bahan ajar pada kelas kontrol keduanya efektif maka dilakukan uji lanjutan. Uji lanjutan yang digunakan adalah uji multivariat Hotelling Trace.

\section{HASIL DAN PEMBAHASAN}

Produk yang dikembangkan pada penelitian ini adalah bahan ajar educational statistics untuk mengembangkan kemandirian belajar dan hasil belajar mahasiswa. Tahapan-tahapan pengembangan bahan ajar pada penilitian ini dijabarkan sebagai berikut:

\section{Tahap define}

Analisis permasalahan yang terjadi pada perkuliahan educational statistics di Program Studi Pendidikan Bahasa Inggris UAD dilakukan dengan membagikan kuesioner dan wawancara. Kuesioner diberikan kepada mahasiswa berisi tentang kebutuhan mahasiswa dalam perkuliahan educational statistics. Hasil kuesioner dan wawancara menunjukkan bahwa mahasiswa mengalami kesulitan dalam mempelajari materi-materi dalam perkuliahan statistika. Kesulitan itu bermula dari minat mahasiswa terhadap mata kuliah educational statistics. Sejak awal kuliah di Program Studi Pendidikan Bahasa Inggris sebagian besar tidak berpikir wajib menempuh mata kuliah statistika. Kemudian ketika perkuliahan belum disediakan bahan ajar yang susunan materinya sesuai dengan kurikulum KKNI di program studi tersebut. Mahasiswa masih sangat menggantungkan materi yang disiapkan oleh dosen, sehingga ketika perkuliahan berlangsung jarang sekali mahasiswa siap atau sudah mempelajari materi dari sumber-sumber yang ada.

Aktivitas yang dilakukan pada tahap define yaitu analisis masalah, analisis peserta didik, analisis materi, analisis tugas, dan analisis tujuan pembelajaran. Analisis masalah dilakukan dengan tujuan untuk mengetahui masalah dasar yang dihadapi dalam pembelajaran. Berdasarkan hasil evaluasi pada akhir proses pembelajaran, masih diperlukan buku pegangan yang menyajikan materi sesuai dengan kurikulum. Sudah banyak tersedia buku tentang statistika, tetapi mahasiswa menyampaikan bahwa materi yang disajikan dalam sebagian besar buku tersebut belum sesuai dengan kompetensi yang telah ditetapkan oleh prodi dan harus dicapai oleh mahasiswa. Selain itu, buku yang sudah ada menyajikan contoh permasalahan di luar bidang pendidikan, padahal mahasiswa FKIP disiapkan agar bisa menjadi guru yang professional. Dengan demikian akan dikembangkan bahan ajar yang dapat memfasilitasi mahasiswa agar dapat belajar secara mandiri.

Mahasiswa yang menempuh mata kuliah educational statistics merupakan mahasiswa di luar program studi pendidikan matematika. Salah satu 
alasan utama mahasiswa memilih program studi selain matematika adalah karena mahasiswa tidak ingin bertemu dengan mata kuliah tentang perhitungan. Ketika mahasiswa mengetahui ada mata kuliah educational statistics maka yang dipikirkan adalah mata kuliah yang isinya hitunghitungan. Karakteristik mahasiswa seperti ini menuntut penyusunan bahan ajar yang tidak memberikan kesan bahwa matematika itu rumit. Dalam penyusunan bahan ajar ini akan ditampilkan contoh soal yang mudah untuk diselesaikan sehingga kesan bahwa matematika itu mudah akan mengubah mindset awal tentang matematika.

Berdasarkan hasil observasi selama proses pembelajaran, seluruh mahasiswa akan memperhatikan penjelasan dari dosen pada menit-menit awal pembelajaran. Setelah pembelajaran berjalan selama lebih dari 15 menit akan terjadi pergeseran fokus mahasiswa. berbeda ketika pembelajaran yang dilakukan adalah pembelajaran yang menuntut mahasiswa berpartisipasi aktif atau menuntut mahasiswa untuk beraktivitas. Berdasarkan karakteristik ini maka bahan ajar dikembangkan secara interaktif dan memfasilitasi terjadinya kolaborasi antar mahasiswa dalam proses pembelajaran.

Berdasarkan hasil analisis terhadap kompetensi dalam kurikulum KKNI maka secara umum materi pada mata kuliah educational statistics dibagi menjadi 2, yaitu statistika deskriptif dan statistika inferensia. Materi yang dikembangkan dalam bahan ajar ini adalah statistika deskriptif. Berdasarkan hasil analisis terhadap karakteristik mahasiswa maka tugas dirancang untuk dapat mengembangkan kemandirian belajar mahasiswa.

\section{Tahap design}

Kegiatan yang dilakukan pada tahap ini merupakan kegiatan yang berkaitan dengan beberapa perancangan. Perancangan yang dilakukan meliputi pemilihan media, pemilihan format, dan perancangan awal. Media yang dikembangkan dalam penelitian ini adalah bahan ajar mata kuliah educational statistics berupa buku ajar yang akan menjadi acuan mahasiswa dalam mata kuliah educational statistics. Kerangka buku yang akan dikembangkan meliputi materi sebagai berikut: halaman sampun; identitas buku; kata pengantar; daftar isi; materi meliputi (a) pengantar statistika; (b) penyajian data; (c) ukuran tendensi sentral; (d) ukuran letak data; (e) ukuran sebaran data; (4) koefisien korelasi; daftar pustaka. Bahan ajar yang dikembangkan memiliki beberapa karakteristik sebagai berikut (a) Bahan ajar yang interaktif, bahan ajar ini memfasilitasi terjadinya interaksi antarmahasiswa untuk dapat belajar; (b) Materi yang disajikan memuat konteks kehidupan dalam dunia pendidikan; (c) Contoh soal yang disajikan merupakan contoh soal yang sederhana sehingga kesan yang ada pada mahasiswa bahwa matematika itu sederhana.

\section{Tahap develop}

Perancangan awal menjadi dasar untuk mengembangkan bahan ajar. Bahan ajar dikembangkan sesuai dengan karakteristik. Pada Gambar 3 disajikan contoh aktivitas untuk memfasilitasi terjadinya interaksi antar mahasiswa untuk saling belajar. 
DOI: https://doi.org/10.24127/ajpm.v9i4.3167

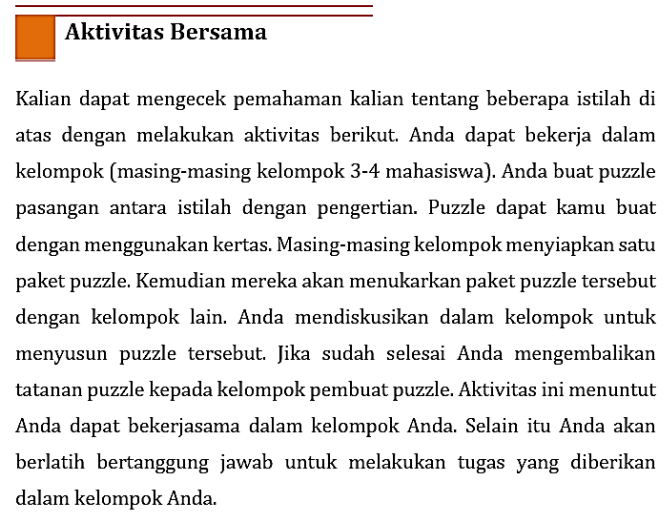

Gambar 2. Contoh aktivitas untuk memfasilitasi interaksi antar mahasiswa.

Beberapa aktivitas juga memfasilitasi mahasiswa untuk melakukan eksplorasi secara berkelompok. Sebagai contoh seperti pada Gambar 3 bagian penyajian data. Bahan ajar menyajikan contoh penyajian data tanpa menyebutkan menggunakan aplikasi tertentu, kemudian mahasiswa diberikan aktivitas untuk menyajikan data dengan menggunakan Microsoft Excel atau SPSS.

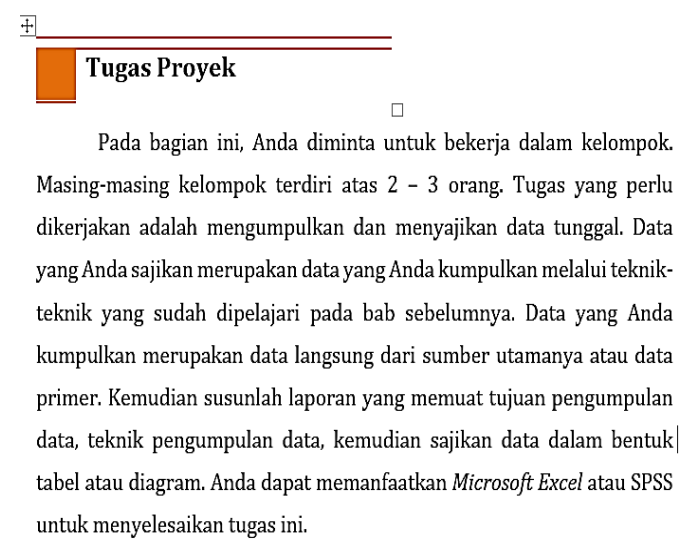

Gambar 3. Aktivitas mandiri mahasiswa untuk melakukan eksplorasi

Bahan ajar yang sudah tersusun kemudian divalidasi oleh ahli. Proses validasi dilakukan dengan expert judgment. Skor validasi ahli materi yaitu 103 dari skor maksimal 130, berada pada kategori valid. Selain itu, validator juga memberikan masukanmasukan yang disajikan pada Tabel 2 .

Tabel 2. Masukan perbaikan dari ahli materi.

\begin{tabular}{ll}
\hline No & \multicolumn{1}{c}{ Masukan ahli } \\
\hline 1 & Materi \\
& $\begin{array}{l}\text { Perlu ditambahkan materi tentang skewness dan kurtosis } \\
\text { Sumber belajar }\end{array}$ \\
& $\begin{array}{l}\text { Perlu ditambahkan referensi } \\
\text { mandiri }\end{array}$ \\
\hline
\end{tabular}

Masukan perbaikan dari ahli dijadikan pedoman untuk melakukan perbaikan bahan ajar. Pada bab ukuran sebaran data ditambahkan materi tentang skewness dan kurtosis. Kedua materi ini akan memberikan pengetahuan awal kepada mahasiswa tentang distribusi data. Pada bahan ajar juga ditambahkan sumber belajar baik berupa artikel maupun video yang berkaitan dengan materi dengan tujuan agar mahasiswa memiliki cukup referensi untuk melakukan pembelajaran secara mandiri.
Bahan ajar yang diujicobakan untuk mengetahui kepraktisan bahan ajar. Bahan ajar diujicobakan kepada 49 mahasiswa. Rata-rata skor hasil kuesioner kepraktisan yang dibagikan kepada mahasiswa yaitu 63,77. Berdasarkan kriteria maka bahan ajar berada pada kategori sangat praktis.

Keefektifan penggunaan bahan ajar diketahui dengan membandingkan hasil dari kelas yang menggunakan bahan ajar yang dikembangkan (kelas eksperimen) dengan kelas yang tidak 
menggunakan bahan ajar tersebut (kelas kontrol).

Uji efektivitas menggunakan pretest-posttest nonequivalent comparison-group design dengan visualisasi pada Gambar 4.
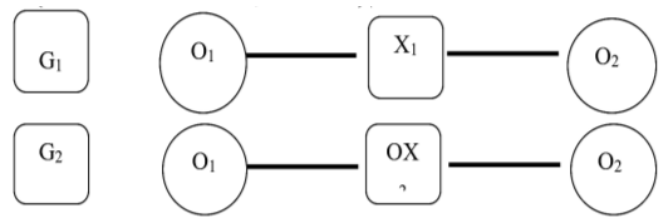

Gambar 4. Uji Coba dengan menggunakan pretest-posttest nonequivalent comparison-group design

Keterangan:

$\mathrm{G}_{1}$ : Kelas Eksperimen

$\mathrm{G}_{2}$ : Kelas kontrol

$\mathrm{O}_{1}$ : Tes dan Angket Sebelum Perlakuan

$\mathrm{O}_{2}$ : Tes dan Angket Setelah Perlakuan

$\mathrm{X}_{1}$ : Penggunaan bahan ajar educational statistics yang dikembangkan

$\mathrm{X}_{2}$ : Penggunaan bahan ajar educational statistics selain yang dikembangkan

\section{Hasil Uji Perbedaan Rata-Rata Data Pretest}

Langkah pertama yang dilakukan yaitu uji perbedaan rata-rata sebelum diberikan perlakuan. Akan tetapi sebelum dilakukan uji ini, terlebih dahulu dilakukan uji asumsi normalitas dan homogenitas terhadap data pretest. Data berdistribusi normal karena semua nilai signifikansi uji lebih dari 0,05 seperti pada Tabel 3.

Tabel 3. Uji normalitas Kolmogorov Smirnov data pretest

\begin{tabular}{lccc}
\hline & \multicolumn{1}{c}{ Kelas } & Statistic & Sig. \\
\hline HB_Pre & $\mathrm{K}$ & .117 & .093 \\
\cline { 2 - 4 } & $\mathrm{E}$ & .112 & .167 \\
\hline Kemandirian_Pre & $\mathrm{K}$ & .102 & $.200^{*}$ \\
\cline { 2 - 4 } & $\mathrm{E}$ & .102 & $.200^{*}$ \\
\hline
\end{tabular}

Sedang untuk homogenitas data diuji dengan menggunakan uji Levene.
Signifikansi pada uji Levene untuk variabel kemandirian belajar sebesar 1,000 sedangkan signifikansi untuk variabel hasil belajar sebesar 0,073. Signifikansi pada kedua variabel bernilai lebih dari 0,05 sehingga kedua variabel memenuhi asumsi homogenitas.

Kedua asumsi (normalitas dan homogenitas) sudah dipenuhi. Langkah selanjutnya adalah menguji apakah ada perbedaan rata-rata sebelum perlakuan untuk kedua kelas. Uji ini menggunakan uji multivariat $T^{2}$ Hotelling's (MANOVA) selanjutnya nilai tersebut ditransformasikan untuk memperoleh nilai distribusi F. Hasil uji beda rata-rata ditunjukkan pada Tabel 4.

Tabel 4. Hasil manova sebelum perlakuan.

\begin{tabular}{lrlr}
\hline Effect & Value & F & Sig. \\
\hline Kelas & .009 & $.421^{\mathrm{b}}$ & .658 \\
\hline
\end{tabular}

Nilai signifikansi uji $T^{2}$ Hotelling's lebih besar dari 0,05 yaitu 0,658 . Artinya, tidak terdapat perbedaan kemampuan awal antara kelas eksperimen dengan kelas kontrol ditinjau dari aspek kemandirian belajar dan hasil belajar mahasiswa.

\section{Uji keefektifan penggunaan bahan ajar}

Langkah berikutnya yaitu dilakukan uji keefektifan dengan penggunaan bahan ajar educational statistics ditinjau dari kemandirian belajar dan hasil belajar mahasiswa terhadap proses pembelajaran kelas eksperimen, diperoleh nilai $\mathrm{t}$ seperti pada Tabel 5. Berdasarkan Tabel 5, diperoleh informasi bahwa nilai signifikansi t untuk kemandirian belajar dan hasil belajar mahasiswa kurang dari 0,05. Artinya, Ho ditolak. Atau dengan kata lain, penggunaan bahan ajar educational statistics efektif ditinjau 
DOI: https://doi.org/10.24127/ajpm.v9i4.3167

dari aspek kemandirian belajar dan hasil belajar mahasiswa.

Tabel 5. Hasil uji one sample t-test kelas eksperimen

\begin{tabular}{lcc}
\hline & $\boldsymbol{t}$ & Sig. \\
\hline $\begin{array}{l}\text { HB_Post_E } \\
\text { (test value }=80)\end{array}$ & 5.523 & .000 \\
\hline $\begin{array}{l}\text { Kemandirian_Post_E } \\
\text { test value }=133.5)\end{array}$ & 16.857 & .000 \\
\hline
\end{tabular}

Pada kelas kontrol juga dilakukan uji keefektifan pembelajaran tanpa menggunakan bahan ajar educational statistics yang dikembangkan ditinjau dari kemandirian belajar dan hasil belajar mahasiswa, diperoleh nilai $t$ seperti pada Tabel 6.

Tabel 6. Hasil uji one sample t-test kelas kontrol

\begin{tabular}{lcc}
\hline & $\mathrm{t}$ & Sig. \\
\hline $\begin{array}{l}\text { HB_Post_E } \\
\text { (test value }=80 \text { ) }\end{array}$ & 4.748 & .000 \\
\hline $\begin{array}{l}\text { Kemandirian_Post_E } \\
\text { (test value = 133.5) }\end{array}$ & 11.085 & .000 \\
\hline
\end{tabular}

Berdasarkan Tabel 6, diperoleh informasi bahwa nilai signifikansi $t$ untuk kemandirian belajar dan hasil belajar mahasiswa kurang dari 0,05. Artinya, Ho ditolak. Atau dengan kata lain, pembelajaran tanpa menggunakan bahan ajar educational statistics yang dikembangkan efektif ditinjau dari aspek kemandirian belajar dan hasil belajar mahasiswa.

Hasil uji efektivitas pada kedua kelas yaitu sama. Pembelajaran menggunakan bahan ajar yang dikembangkan dan tidak menggunakan bahan ajar yang dikembangkan keduanya efektif ditinjau dari kemandirian belajar dan hasil belajar mahasiswa. Berdasarkan hasil ini maka dilakukan uji berikutnya yaitu uji beda rata-rata dari hasil postest pada kedua kelas. Uji yang dilakukan menggunakan uji $T^{2}$ Hotelling's. Hasil uji beda ratarata ditunjukkan pada Tabel 7 .

Tabel 7. Hasil manova setelah perlakuan.

\begin{tabular}{lccc}
\hline Effect & Value & F & Sig. \\
\hline Kelas & .029 & $1.355^{\text {b }}$ & .263 \\
\hline
\end{tabular}

Berdasarkan Tabel 7, diperoleh informasi bahwa nilai signifikansi lebih dari 0,05 untuk data setelah perlakuan. Artinya, kedua kelas tersebut tidak memiliki perbedaan keefektifan untuk kedua aspek yang diukur. Atau dengan kata lain, tidak terdapat perbedaan keefektifan penggunaan bahan ajar educational statistics dan tanpa penggunaan bahan ajar tersebut.

Berdasarkan hasil penelitian di atas diketahui bahwa penggunaan bahan ajar educational statistics efektif ditinjau dari kemandirian belajar mahasiswa. Bahan ajar memberikan dukungan untuk pencapaian indikator kemandirian belajar yaitu pengaturan diri, kebiasaan kerja, dan lingkungan belajar.

Pengaturan diri meliputi organisasi dan tranformasi, pencarian informasi, latihan dan mengingat kembali, meninjau kembali catatan. Bahan ajar dikembangkan dengan urutan materi yang sistematis dan runtut. Mahasiswa akan belajar secara runtut pada materi statistika deskriptif. Selain itu penyajian materi yang didasarkan pada masalah yang sering dihadapi oleh mahasiswa pada dunia pendidikan akan dapat menstransformasikan pikiran mahasiswa dari berpikir konkrit ke berpikir abstrak. Bahan ajar ini dilengkapi bagian rubrik "tahukah kamu". Rubrik ini akan membantu mahasiswa dalam mengembangkan pengetahuannya. Salah satu contoh adalah penggunaan teknologi. Pada bagian ini tidak dijelaskan secara 
detail tetapi mahasiswa dituntut untuk mencari lebih lanjut informasi yang berkaitan. Hal tersebut akan memotivasi mahasiswa untuk lebih banyak menggali informasi. Pada bagian akhir setiap bab disajikan latihan bagi mahasiswa untuk mengukur ketercapaian kompetensi. Hal-hal tersebut dapat mendukung tercapainya indikator pengaturan diri.

Indikator berikutnya adalah kebiasaan kerja yang meliputi aspek evaluasi diri, membuat catatan. Indikator ini tercapai dengan ada dukungan pada bagian rubrik latihan.

Indikator terakhir adalah lingkungan belajar yang meliputi aspek penataan lingkungan dan pencarian bantuan sosial. Kedua aspek ini dapat tercapai karena bahan ajar dikembangkan berbasis pada pembelajaran kooperatif. Beberapa permasalahan yang disajikan dai dalam bahan ajar harus diselesaikan oleh mahasiswa secara berkelompok. Kerja dalam kelompok yang dilakukan mahasiswa menuntu mahasiswa untuk dapat mengkondisikan anggotanya dan menciptakan lingkungan yang nyaman agar terjadi diskusi yang baik. Dengan adanya kegiatan diskusi ini maka mahasiswa terdorong untuk menanyakan kesulitan yang dialami kepada temannya.

Penggunaan bahan ajar educational statistics efektif jika ditinjau dari kemandirian belajar mahasiswa. Hal tersebut sejalan dengan penelitian yang dilakukan oleh Pramana and Dewi (2014), Mulyani, Hidayat, and Lisnawati (2015), dan Novalia and Noer (2019). Hasil penelitian yang dilakukan oleh ketiga peneliti tersebut menyatakan bahwa penggunaan bahan ajar pada saat pembelajaran dapat meningkatkan kemandirian belajar peserta didik. Perbedaan ketiga penelitian tersebut dengan penelitian ini terletak pada pemilihan pendekatan pembelajaran yang digunakan dalam bahan ajar.

Bahan ajar educational statistics juga efektif ditinjau dari hasil belajar mahasiswa. Pada bahan ajar disajikan konsep-konsep tentang statistika deskriptif, kemudian disajikan contohcontoh penerapan dari konsep tersebut. Mahasiswa diberi kesempatan untuk berlatih menyelesaikan tes berkaitan dengan materi. Hal ini mendukung tercapainya hasil belajar yang bagus oleh mahasiswa.

Penggunaan bahan ajar educational statistics jika dibandingkan dengan penggunaan bahan ajar yang lain tidak lebih efektif ditinjau dari kemandirian belajar dan hasil belajar mahasiswa. Hal ini diduga disebabkan oleh beberapa aspek yaitu bahan ajar yang seharusnya digunakan dalam versi cetak tetapi mahasiswa menggunakannya dalam versi softfile. Beberapa aktivitas yang ada dalam bahan ajar masih belum dilakukan oleh mahasiswa jika dosen tidak menanyakannya. Dalam hal ini sangat penting bagi seorang dosen untuk selalu menjaga komunikasi dan memberikan feedback terkait dengan aktivitas pembelajaran mahasiswa.

\section{KESIMPULAN DAN SARAN}

Bahan ajar educational statistics yang dikembangkan memenuhi kriteria valid. Berdasarkan uji efektivitas pada kelas eksperimen dan kelas kontrol, pembelajaran dengan menggunakan bahan ajar yang dikembangkan dan pembelajaran seperti biasanya menunjukkan bahwa keduanya efektif ditinjau dari kemandirian belajar dan hasil belajar. Kemudian hasil uji lanjut menunjukkan bahwa penggunaan bahan ajar yang dikembangkan tidak lebih 
efektif, oleh karena itu perlu dilakukan penelitian lanjut untuk mengembangkan lagi bahan ajar agar bisa lebih efektif digunakan untuk mengembangkan kemandirian belajar dan hasil belajar mahasiswa.

\section{DAFTAR PUSTAKA}

Aisyah, S., Noviyanti, E., \& Triyanto. (2020). Bahan Ajar Sebagai Bagian Dalam Kajian Problematika Pembelajaran Bahasa Indonesia. Jurnal Salaka, 2, 6265.

Astuti, D. (2019). Analisis kebutuhan bahan ajar educational statistics berbasis cooperative learning. Fibonacci, 5(2), 183-188.

Azka, R., \& Santoso, R. H. (2015). Pengembangan Perangkat Pembelajaran Kalkulus Untuk Mencapai Ketuntasan Dan Kemandirian Belajar Siswa. Jurnal Riset Pendidikan Matematika, 2(1), $\quad 78$. https://doi.org/10.21831/jrpm.v2i1. 7152

Azwar, S. (2013). Tes prestasi: fungsi dan pengembangan pengukuran prestasi belajar (II). Yogyakarta: Pustaka Pelajar Offset.

Cole, P. G., \& Chan, L. (1994). Teaching Principle and Practice. Canberra: Prentice.

Day, S. L., \& Connor, C. S. C. (2012). Examining the relations between self-regulation and academic achievement in third grade students. 3551128, 80.

de Bruin, A. B. H., Thiede, K. W., Camp, G., \& Redford, J. (2011). Generating keywords improves metacomprehension and selfregulation in elementary and middle school children. Journal of Experimental Child Psychology, 109(3), 294-310. Retrieved from https://www.sciencedirect.com/scie nce/article/abs/pii/S002209651100 0373

Gafoor, A., \& Kurukkan, A. (2015). Why High School Students Feel Mathematics Difficult? An Exploration of Affective Beliefs. In Online Submission.

Harris, K. R., Friedlander, B. D., Saddler, B., Frizzelle, R., \& Graham, S. (2005). Selfmonitoring of attention versus self-monitoring of academic performance: Effects among students with ADHD in the general education classroom. Journal of Special Education, 39(3), 145-156.

Hidayat, F., Akbar, P., \& Bernard, M. (2008). Analisis kemampuan berfikir kritis matematik serta kemandiriaan belajar siswa smp terhadap materi SPLDV. Journal On Education, 01(02), 515-523.

Järvelä, S., \& Järvenoja, H. (2011). Socially constructed self-regulated learning and motivation regulation in collaborative learning groups. Teachers College Record, 113(2), 350-374.

Krisdiana, I. (2016). Pengembangan Perangkat Pembelajaran Pada Matakuliah Statistika Dasar Dengan Metode Problem Based Learning. Jurnal Edukasi Matematika Dan Sains, 4(1), 61. https://doi.org/10.25273/jems.v4i1. 220

Latifah, U. H., \& Widjajanti, D. B. (2017). Pengembangan bahan ajar statistika dan peluang berbasis multiple intelligences berorientasi pada prestasi, pemecahan masalah, dan rasa ingin tahu. Jurnal Riset Pendidikan Matematika, 4(2), 176. https://doi.org/10.21831/jrpm.v4i2. 13083 
Marchis, I. (2011). How Mathematics Teachers Develop Their Pupils' Self -Regulated Learning Skills. Acta Didactica Napocensia, 4(2).

Merona, S. P. (2019). Penggunaan Modul Statitistika Matematika Untuk Meningkatkan Kemandirian Belajar Mahasiswa Prodi Pendidikan Matematika FKIP Universitas Muhammadiyah Ponorogo. Jurnal Dimensi Pendidikan Dan Pembelajaran, 7(1).

Mulyani, L., Hidayat, A., \& Lisnawati, C. (2015). Pengembangan Bahan Ajar Smartbook Berbasis Sains untuk Meningkatkan Kemandirian Belajar. JP2EA (Jurnal Pendidikan Dan Pembelajaran Ekonomi Akuntansi), 1, 22-32.

Novalia, H., \& Noer, S. H. (2019). Pengembangan Modul Pembelajaran Matematika Dengan Strategi Pq4R Untuk Meningkatkan Kemampuan Berpikir Kreatif Dan Kemandirian Belajar Siswa Sma. Jurnal Penelitian Dan Pembelajaran Matematika, $12(1)$. https://doi.org/10.30870/jppm.v12i 1.4854

Numan, M. (2019). Pengembangan Bahan Ajar Statistika Penelitian Pendidikan Matematika. Jurnal Mercumatika: Jurnal Penelitian Matematika Dan Pendidikan Matematika, 3(2), 114. https://doi.org/10.26486/jm.v3i2.7 62

Pramana, W. D., \& Dewi, N. R. (2014). Pengembangan E-Book Ipa Terpadu Tema Suhu Dan Pengukuran Untuk Menumbuhkan Kemandirian Belajar Siswa. USEJ -Unnes Science Education Journal,
3(3). https://doi.org/10.15294/ usej.v3i3.4267

Rembulan, A., Wahyu, R., \& Putra, Y. (2018). Pengembangan Bahan Ajar Gamifikasi. Jurnal Matematika Dan Pendidikan Matematika, 3(2), 84-98.

Tian, B. (2003). Pengembangan Bahan Ajar. Jakarta: Pusat Penerbitan UT. Timmons, K., Pelletier, J., \& Corter, C. (2016). Understanding children's self-regulation within different classroom contexts. Journal Early Child Development and Care, 186(2), 249-267.

Wilda, Salwah, \& Ekawati, S. (2017). Pengaruh kreativitas dan minat belajar terhadap hasil belajar matematika siswa. Pedagogy: Jurnal Pendidikan Matematika, 2(1), 134-144.

Wolters, C. A. (2011). Regulation of Motivation: Contextual and Social Aspects. Teachers College Record, 113(2), 265-283.

Zimmerman, B. (2008). Investigating Self-Regulation and Motivation: Historical Background, Methodological Developments, and Future Prospects. American Educational Research, 45(1), 166183. Retrieved from https://journals.sagepub.com/doi/a bs/10.3102/0002831207312909

Zumbrunn, S. (2011). Encourage self regulated learning in the classroom. Journal Virginia Commonwealth University, 278299. Retrieved from http://scholarscompass.vcu.edu/me rc_pubs/18 